\title{
QUALITATIVE ANALYSIS OF INTERNAL AND EXTERNAL RISKS FOR READY MIX CONCRETE PLANTS - A CASE STUDY APPROACH
}

\author{
${ }^{1}$ R. C. WALKE, ${ }^{2}$ PROF. V.M. TOPKAR \\ ${ }^{I}$ Research student for Ph. D. course, V. J. T. I., Mumbai University \\ ${ }^{2}$ Head,Civil and Environmental Engineering Department, V. J. T. I., Mumbai University
}

\begin{abstract}
Ready Mix Concrete (RMC) industry is continuously growing all over the world and India is not an exception to it. Like other industries, RMC industry is also exposed to multidimensional risks from all directions. These risks must be addressed properly so that RMC industry shall gain credibility, confidence of the customers and shall have expected profit margins. The risk sources pertaining to RMC industry are internal as well as external. This paper proposes a simple yet effective procedure for qualitative analysis of risks having internal and external sources related to Ready Mix Concrete (RMC) plants. Once the risks are qualitatively analyzed, the appropriate response strategies can be adopted to treat these risks.
\end{abstract}

Key Words - Risk, Multidimensional, RMC,

QUALITATIVE ANALYSIS OF INTERNAL AND EXTERNAL RISKS FOR READY MIX CONCRETE PLANTS-INDIAN CONTEXT

\section{INTRODUCTION}

Ready Mix Concrete (RMC) is a "Concrete delivered at site or into purchaser's vehicle in the plastic condition and requiring no further treatment before being placed in a position in which it is to be set and hardened" (IS 49262001). Ready Mix concrete is environmental friendly. Its manufacturing is not messy and time consuming. It can be provided as per the customer's requirements for specifications and quality. Storing materials at site for manufacturing concrete is not required at project sites.

In India, use and demand of RMC is growing rapidly in civil and construction business. Globalization has given a boost to many infrastructure projects in India. Many companies are foraying in RMC business because it has a huge potential. Anticipating huge potential for RMC, many organized and unorganized players are foraying in this area.

RMC industry is exposed to various risks in India. Risk Management at RMC plant is not given adequate importance the way it is given in European countries, where operation managers at RMC Plant manage risks at production plant and delivery sites (www.learn4good.com). The risk causes of any projects can be categorized into internal and external (Zia,H.1995). With this approach, the risks related to RMC plants can be categorized broadly into internal and external risks.

Proposed paper is focused on qualitative analysis approach for internal and external risks to which RMC plants in India are exposed. Qualitative analysis of risks shall help management of RMC plant to decide upon appropriate response strategies to achieve objectives of RMC business.

\section{RISK MANAGEMENT APPROACH}

Risk Management is a major feature of the management of large engineering projects to reduce uncertainties and to achieve project success. The risk management approach aims to identify and assess risks in order to enable the risks to be understood clearly and managed effectively David Hilson,2002. It is a critical part of project management as 'unmanaged or unmitigated risks are one of the primary causes of project failure' (Lyons and Skitmore, 2004). Failure to perform effective risk management can cause projects to exceed budget, fall behind schedule, miss critical performance targets, or exhibit any combinations of these troubles (Carbone and Tippett 2004). A number of variations of risk management approach have been proposed by different authors and researchers, that in general includes identification, classification and analysis of risks.

Risk identification deals with identification of potential risks affecting the project objectives. Various tools and techniques like Brainstorming, Cause - Effect Diagram, Decision Tree, Delphi Technique, Interviews etc.are used for risk identification. Classification of risks helps in deciding which category of risks is to be focused more for 
analysis and risk response. Authors like Baldwin (1971), Mason (1973), Ashley (1981) and, Johnson and Rood (1977), have given different classifications of risks according to their own perception.

The analysis of risks could be qualitative and quantitative. Qualitative risk analysis includes deciding upon the probability of occurrence of a particular risk and tits consequences to find out the exposure of that particular risk. It is a very is rapid and cost effective method to analyze the risks. It results in a list of potential risks that shall have substantial influence on project objectives in terms of cost, time, quality, safety, health and performance. Risk quantification and analysis of quantified risks can be a step further, if needed, using suitable techniques. Some of the techniques used to analyze risks qualitatively and quantitatively are Probability and impact Grid, Fault tree analysis, Event tree analysis, Sensitivity analysis, Simulation, Decision Tree analysis, Expected value Method, Analytical Hierarchy Process.

Appropriate response strategies can be decided after qualitatively analyzing the risks. PMBOK (2004) has given four response strategies as Risk Avoidance, Risk Transfer, Risk Mitigation and Risk Acceptance.. Appropriate response strategies are selected and implemented for the selected potential risks and are to be monitored continuously. Selection of effective risk response strategies shall reduce the effect of risks on project objectives.

\section{QUALITATIVE ANALYSIS OF RISKS - AN APPROACH PRESENTED IN PROPOSED STUDY}

In the proposed study, risk is considered as a future event which has an adverse effect on the objectives of company running RMC plant and for which possible outcomes can be predicted on the basis of probability. This study considerers risk management as a process having sub- processes like Risk identification, Risk Classification, Risk analysis and Risk response management. In order to identify internal as well as external risks, and to classify them in different categories, interviews of plant managers and other key personnel at RMC plants run by different companies in different location in were conducted. Outcome of this exercise is presented in (Table 1).Table 3 represents categorization of potential risks obtained after qualitative risk analysis.

Table1

Identification of External and External risks in RMC Plants in India

\begin{tabular}{|c|l|c|c|}
\hline Sr No. & Description of risks & Internal & External \\
\hline 1 & Change in Govt. and Govt. policies & & $\checkmark$ \\
\hline 2 & War, Riots etc. & & $\checkmark$ \\
\hline 3 & Interference of local Politicos & & \\
\hline 4 & $\begin{array}{l}\text { Contractual liability (breach, third party } \\
\text { action) }\end{array}$ & $\checkmark$ & \\
\hline 5 & $\begin{array}{l}\text { Inappropriate dispute redressel } \\
\text { mechanism }\end{array}$ & $\checkmark$ & \\
\hline 6 & Conflict between various agencies & $\checkmark$ & \\
\hline 7 & Errors in contract price calculation & $\checkmark$ & \\
\hline 8 & Misinterpretation of contract terms & $\checkmark$ & \\
\hline 9 & Litigation due to claim & $\checkmark$ & \\
\hline 10 & Ambiguity in specification for delivery & $\checkmark$ & \\
\hline 11 & Change in scope & $\checkmark$ & \\
\hline 12 & Air Pollution & $\checkmark$ & \\
\hline 13 & Water Pollution & $\checkmark$ & \\
\hline 14 & Noise Pollution & $\checkmark$ & \\
\hline 15 & Soil Pollution & & \\
\hline 16 & Environmental Litigation & $\checkmark$ & \\
\hline 17 & Depletion of Natural resources & & \\
\hline 18 & Extreme weather conditions (cold / hot) & & \\
\hline 19 & Inflation & & \\
\hline 20 & Delay in Payment by client & & \\
\hline 21 & Investment Risks & & \\
\hline 22 & Interest rate change & & \\
\hline 23 & Force Majeure(Acts of God) & & \\
\hline 24 & Disease / Epidemic & & \\
\hline & & & \\
\hline
\end{tabular}




\begin{tabular}{|c|c|c|c|}
\hline 25 & Fire & & $\checkmark$ \\
\hline 26 & Terrorism & & $\checkmark$ \\
\hline 27 & Natural Disaster & & $\checkmark$ \\
\hline 28 & Changes in local Tax rates & & $\checkmark$ \\
\hline 29 & $\begin{array}{l}\text { Levy of additional taxes and duties on } \\
\text { RMC (Entry Tax, Excise duty) }\end{array}$ & & $\checkmark$ \\
\hline 30 & $\begin{array}{l}\text { Changes in current RMC regulations and } \\
\text { ministry requirements }\end{array}$ & & $\checkmark$ \\
\hline 31 & Changes in local Tax rates & & $\checkmark$ \\
\hline 32 & Use of new technology & $\checkmark$ & \\
\hline 33 & Lack of technical expertise / personnel & $\checkmark$ & \\
\hline 34 & Internal technology system failure & $\checkmark$ & \\
\hline 35 & Improper internal infrastructure & $\checkmark$ & \\
\hline 36 & Improper site access & $\checkmark$ & \\
\hline 37 & Ineffective control over wastage & $\checkmark$ & \\
\hline 38 & Confined spaces & $\checkmark$ & \\
\hline 39 & $\begin{array}{l}\text { regulatory and Govt. requirements for } \\
\text { production }\end{array}$ & & $\checkmark$ \\
\hline 40 & Operational performance risk & $\checkmark$ & \\
\hline 41 & Extended operation hours & $\checkmark$ & \\
\hline 42 & Delay during transportation & & $\checkmark$ \\
\hline 43 & Frequent breakdown of M/Cs, Plant etc. & $\checkmark$ & \\
\hline 44 & $\begin{array}{l}\text { Damage to M/Cs due to flood, accidents } \\
\text { and } \\
\text { during transport of concrete }\end{array}$ & $\checkmark$ & \\
\hline 45 & Wrongly designed layout & $\checkmark$ & \\
\hline 46 & Unskilled personnel at work & $\checkmark$ & \\
\hline 47 & $\begin{array}{l}\text { Risk of accidents loosing production, } \\
\text { loosing life }\end{array}$ & $\checkmark$ & \\
\hline 48 & Traffic problems & & $\checkmark$ \\
\hline 49 & Idle machineries & $\checkmark$ & \\
\hline 50 & Technical Risks - Policies and Procedure & $\checkmark$ & \\
\hline 51 & Loading wrong material & $\checkmark$ & \\
\hline 52 & Oversetting of concrete & $\checkmark$ & \\
\hline 53 & Non setting of concrete & $\checkmark$ & \\
\hline 54 & $\begin{array}{l}\text { Improper infrastructure, scaffolding and } \\
\text { platform }\end{array}$ & $\checkmark$ & \\
\hline 55 & Over utilization of plant capacity & $\checkmark$ & \\
\hline 56 & Wrong working location & $\checkmark$ & \\
\hline 57 & $\begin{array}{l}\text { Improper errection and commissioning of } \\
\text { Plant }\end{array}$ & $\checkmark$ & \\
\hline 58 & $\begin{array}{l}\text { Death/Injury to someone at site or in plant } \\
\text { due to accident }\end{array}$ & $\checkmark$ & \\
\hline 59 & High transportation cost & $\checkmark$ & \\
\hline 60 & $\begin{array}{l}\text { Lack of infrastructural facilities (water, } \\
\text { roads, electricity, communication } \\
\text { systems) }\end{array}$ & $\checkmark$ & \\
\hline 61 & $\begin{array}{l}\text { Use of ungraded machineries in } \\
\text { manufacturing process }\end{array}$ & $\checkmark$ & \\
\hline 62 & Delay due to accidents at site & $\checkmark$ & \\
\hline 63 & $\begin{array}{l}\text { Damage to roads due to transporting } \\
\text { through heavy vehicles }\end{array}$ & $\checkmark$ & \\
\hline 64 & No flow through pipes during discharge & $\checkmark$ & \\
\hline
\end{tabular}




\begin{tabular}{|c|c|c|c|}
\hline 65 & Varying degree of moisture in sand & $\checkmark$ & \\
\hline 66 & $\begin{array}{l}\text { Improper or no calibration of water meter, } \\
\text { weigh balance, machines and equipments }\end{array}$ & $\checkmark$ & \\
\hline 67 & $\begin{array}{l}\text { Errors in testing and inspection of } \\
\text { materials. }\end{array}$ & $\checkmark$ & \\
\hline 68 & $\begin{array}{l}\text { Non availability of advanced testing } \\
\text { facilities. }\end{array}$ & $\checkmark$ & \\
\hline 69 & Poor quality of repairs and maintenance & $\checkmark$ & \\
\hline 70 & Inaccuracy in batching, weighing, mixing & $\checkmark$ & \\
\hline 71 & Inaccuracy in statistical adjustments & $\checkmark$ & \\
\hline 72 & $\begin{array}{l}\text { Risks of drying and loss of workability of } \\
\text { concrete }\end{array}$ & $\checkmark$ & \\
\hline 73 & $\begin{array}{l}\text { Slump and sand content is not properly } \\
\text { governed }\end{array}$ & $\checkmark$ & \\
\hline 74 & $\begin{array}{l}\text { Mixer not maintained in an efficient and } \\
\text { clean condition }\end{array}$ & $\checkmark$ & \\
\hline 75 & Improper moisture compensation & $\checkmark$ & \\
\hline 76 & $\begin{array}{l}1 \\
\text { Incorrect Mix design }\end{array}$ & $\checkmark$ & \\
\hline 77 & Improper specification for RMC & & $\checkmark$ \\
\hline 78 & Incorrect use of admixtures & $\checkmark$ & \\
\hline 79 & Irregular quality monitoring & $\checkmark$ & \\
\hline 80 & Inappropriate quality standards & $\checkmark$ & \\
\hline 81 & $\begin{array}{l}\text { Receiving raw material at site without } \\
\text { required specifications }\end{array}$ & $\checkmark$ & \\
\hline 82 & $\begin{array}{l}\text { Risks related to basic properties of ready } \\
\text { mix concrete like workability, strength, } \\
\text { durability, segregation and homogeneity } \\
\text { during transport }\end{array}$ & $\checkmark$ & \\
\hline 83 & $\begin{array}{l}\text { Not using proper checklist for quality } \\
\text { control }\end{array}$ & $\checkmark$ & \\
\hline 84 & $\begin{array}{l}\text { Non availability / shortage of cement and } \\
\text { other materials }\end{array}$ & $\checkmark$ & \\
\hline 85 & Transport strike & & $\checkmark$ \\
\hline 86 & Vender problems (delays) & & $\checkmark$ \\
\hline 87 & Poor quality of materials & $\checkmark$ & \\
\hline 88 & Non availability of spare parts & & $\checkmark$ \\
\hline 89 & Difficulties in importing equipments & & $\checkmark$ \\
\hline 90 & Raw material selection risk & $\checkmark$ & \\
\hline 91 & $\begin{array}{l}\text { Improper storage system (Dampness, no } \\
\text { ventilation) }\end{array}$ & $\checkmark$ & \\
\hline 92 & Theft at site & $\checkmark$ & \\
\hline 93 & $\begin{array}{l}\text { Risks associated with buying and /or } \\
\text { hiring decisions }\end{array}$ & $\checkmark$ & \\
\hline 94 & Eye, skin and respiratory tract irritation & $\checkmark$ & \\
\hline 95 & Chemical burns & $\checkmark$ & \\
\hline 96 & Over exertion & $\checkmark$ & \\
\hline 97 & Ergonomics & $\checkmark$ & \\
\hline 98 & $\begin{array}{l}\text { Occupational hazards faced by truck } \\
\text { drivers }\end{array}$ & $\checkmark$ & \\
\hline 99 & Injuries at site & $\checkmark$ & \\
\hline 100 & Slips, trips and falls & $\checkmark$ & \\
\hline 101 & Accidents at site & $\checkmark$ & \\
\hline 102 & Non functioning of fire fighting system at & $\checkmark$ & \\
\hline
\end{tabular}




\begin{tabular}{|c|c|c|c|}
\hline & site & & \\
\hline 103 & $\begin{array}{l}\text { Non availability /no use of safety } \\
\text { equipments and tools at site }\end{array}$ & $\checkmark$ & \\
\hline 104 & Unavailability of proper medical facilities & $\checkmark$ & \\
\hline 105 & Mishandling of material at site & $\checkmark$ & \\
\hline 106 & Demand - Supply Gap & $\checkmark$ & \\
\hline 107 & Competition in Market & & $\checkmark$ \\
\hline 108 & $\begin{array}{l}\text { Wrong assessment of market potential and } \\
\text { demand estimation. }\end{array}$ & $\checkmark$ & \\
\hline 109 & Problems created by nearby residents & & $\checkmark$ \\
\hline 110 & $\begin{array}{l}\text { Public outcry with regard to activities like } \\
\text { quarrying near plant etc }\end{array}$ & & $\checkmark$ \\
\hline 111 & $\begin{array}{l}\text { Non productivity / performance of } \\
\text { laborers }\end{array}$ & $\checkmark$ & \\
\hline 112 & Non availability of local labor & & $\checkmark$ \\
\hline 113 & High Labor turnover & $\checkmark$ & \\
\hline 114 & Problems by labor union & & $\checkmark$ \\
\hline 115 & Cultural differences & & $\checkmark$ \\
\hline 116 & Performance risks & $\checkmark$ & \\
\hline 117 & Improper planning for various works & $\checkmark$ & \\
\hline 118 & $\begin{array}{l}\text { Less growth opportunities within } \\
\text { organization }\end{array}$ & $\checkmark$ & \\
\hline 119 & $\begin{array}{l}\text { Discharge of concrete on ground (slurry is } \\
\text { lost) }\end{array}$ & $\checkmark$ & \\
\hline 120 & Improper mixing & $\checkmark$ & \\
\hline 121 & $\begin{array}{l}\text { No policy for solid waste and runoff } \\
\text { management }\end{array}$ & $\checkmark$ & \\
\hline 122 & Inappropriate disposal of sludge & $\checkmark$ & \\
\hline 123 & $\begin{array}{l}\text { Conveyance of waste water is not } \\
\text { regulated properly }\end{array}$ & $\checkmark$ & \\
\hline 124 & $\begin{array}{l}\text { Inappropriate sewage treatment and } \\
\text { disposal }\end{array}$ & $\checkmark$ & \\
\hline 125 & Low maintenance & $\checkmark$ & \\
\hline 126 & $\begin{array}{l}\text { No careful planning is done for repairs } \\
\text { and maintenance }\end{array}$ & $\checkmark$ & \\
\hline 127 & $\begin{array}{l}\text { No periodical check up of plant and } \\
\text { machineries }\end{array}$ & $\checkmark$ & \\
\hline 128 & $\begin{array}{l}\text { Not following manufacturers } \\
\text { recommended practice for cleaning and } \\
\text { lubricating etc }\end{array}$ & $\checkmark$ & \\
\hline 129 & $\begin{array}{l}\text { Not maintaining maintenance check sheet } \\
\text { and repair records }\end{array}$ & $\checkmark$ & \\
\hline 130 & $\begin{array}{l}\text { No set up for regular testing and } \\
\text { inspection }\end{array}$ & $\checkmark$ & \\
\hline 131 & $\begin{array}{l}\text { Major overhauling is not done by } \\
\text { manufacturer's representative or } \\
\text { specialist/ experts. }\end{array}$ & $\checkmark$ & \\
\hline 132 & $\begin{array}{l}\text { Worn parts are not replaced on regular } \\
\text { basis }\end{array}$ & $\checkmark$ & \\
\hline 133 & $\begin{array}{l}\text { Hydraulic equipment is not kept free from } \\
\text { contamination. }\end{array}$ & $\checkmark$ & \\
\hline
\end{tabular}


Qualitative risk analysis was done using five point scales for probability and Impact. This Five po140 scale was used to get the probabilities and impact values on subjective basis (1 to 5 - standing for very low, low, medium, high and very high respectively). A high probability of very low impact and very low probability of a very high impact is not considered as a risky condition. Only when both, the probability of occurrence and the Impact are significant, the situation is considered risky (Baloi Daniel et.al; 2004). On the basis of this concept, the risk acceptance criteria was defined and decided in the proposed study (Table 2). For example, Probability of occurrence of Health risks is very high in RMC plant and Impact is also high considering the importance of human life. Hence exposure of this risk is considered very high. This risk is thus considered for the further process in risk management i.e. for risk quantification and quantitative risk analysis. Similarly, risks with low probability of occurrence and low Impact will have low exposure and thus can be excluded from further process in risk management.

Table 2

Combination of the probability and Impact for risks to be considered for Quantification

\begin{tabular}{|c|}
\hline $\begin{array}{c}\text { Very High Probability - Very High Impact } \\
\text { Very High Probability - High Impact }\end{array}$ \\
\hline Very High Probability - Medium Impact \\
\hline High Probability - Very High Impact \\
\hline High Probability - High Impact \\
\hline High Probability - Medium Impact \\
\hline Medium Probability - Very High Impact \\
\hline Medium Probability - High Impact \\
\hline Medium Probability - Medium Impact \\
\hline
\end{tabular}

With the help of Probability -Impact ranges and the acceptance criteria decided upon, a screened list of risks is obtained which will actually have substantial influence on objective of a company running RMC plant. These screened risks are then assigned different sub- categories like political, environmental, legal-contractual, financial, operational, safety, repairs and maintenance, quality, procurement and storage, market and organizational risks. This list is to be taken into account to decide upon suitable response strategies (Table 3). This sub-categorization is important because management of RMC plant may be interested in deciding upon response strategy only for the risks falling under a particular category and may ignore other categories of risks for various reasons.

Table 3

Selective risks having significant impact

\begin{tabular}{|c|l|l|l|l|}
\hline No. & \multicolumn{1}{|c|}{ Significant Risks } & $\begin{array}{l}\text { Risk } \\
\text { Category - } \\
\text { Internal }\end{array}$ & $\begin{array}{l}\text { Risk Category } \\
- \text { External }\end{array}$ & $\begin{array}{c}\text { Risk } \\
\text { Sub-Category }\end{array}$ \\
\hline 1. & Interference of local politicos & & $\checkmark$ & Political \\
\hline 2. & $\begin{array}{l}\text { Inappropriate dispute redressal } \\
\text { mechanism }\end{array}$ & $\checkmark$ & $\begin{array}{l}\text { Legal/Contractu } \\
\text { al }\end{array}$ \\
\hline 3. & Conflict between various agencies & $\checkmark$ & $\begin{array}{l}\text { Legal/Contractu } \\
\text { al }\end{array}$ \\
\hline
\end{tabular}




\begin{tabular}{|c|l|l|l|l|}
\hline 4. & Extreme weather conditions & & $\checkmark$ & Environmental \\
\hline 5. & Delay in payment by client & & $\checkmark$ & Financial \\
\hline 6. & Delay during transportation & & $\checkmark$ & Operational \\
\hline 7. & Wrongly designed layout & $\checkmark$ & & Operational \\
\hline 8. & Accidents at site & $\checkmark$ & & Safety \\
\hline 9. & Loading wrong material & $\checkmark$ & & Operational \\
\hline 10. & $\begin{array}{l}\text { No periodical check up of plant and } \\
\text { machineries }\end{array}$ & $\checkmark$ & & $\begin{array}{l}\text { Repairs and } \\
\text { Maintenance }\end{array}$ \\
\hline 11. & $\begin{array}{l}\text { Receiving raw material at site without } \\
\text { required specifications }\end{array}$ & $\checkmark$ & & Quality \\
\hline 12. & Vendor problems(delays) & & $\checkmark$ & $\begin{array}{l}\text { Procurement } \\
\text { and storage }\end{array}$ \\
\hline 13. & $\begin{array}{l}\text { Unavailability of proper medical } \\
\text { facilities }\end{array}$ & $\checkmark$ & & Safety \\
\hline 14. & competition in market & & $\checkmark$ & Market \\
\hline 15. & $\begin{array}{l}\text { Wrong assessment and market } \\
\text { potential and demand estimation }\end{array}$ & $\checkmark$ & & Market \\
\hline 16. & $\begin{array}{l}\text { Less growth opportunities within an } \\
\text { organization }\end{array}$ & $\checkmark$ & & Organizational \\
\hline
\end{tabular}

\section{CONCLUSION}

The proposed paper presents an approach for qualitative analysis of internal as well as external risks is RMC plants at various locations in India. On the basis of the information gathered, a checklist of risks is generated. Subjective ratings for both, probability of occurrence and Impact were applied to these risks in order to qualitatively analyze them. An acceptance and rejection criteria is suggested to screen the risks having significant impact on the objectives of companies running RMC plants. Thus, qualitative analysis resulted into a list of potential risks. Suitable response strategies for these screened risks can be decided upon by the management of respective RMC plant.

\section{REFERENCES:}

1 Ashley, D. B.(1981), Construction project Risks: Mitigation and Management, Proc., PMI/Internet Joint Symp., Project Management Institute, Drexel Hill, Pa., pp. 331-340.

2 Baloi Daniel (2003) Modeling global risk factors affecting construction cost performance, International journal of project management, 21(2003), pp. 261-269

3 Baldwin, J.R.(1971), Causes of delay in construction industry, Journal of Construction Div, ASCE, pp 105106

4 David Hilson (2002), Use a Risk Breakdown Structure (RBS) TO Understand Your Risks, Proceedings of the Project Management Institute Annual Seminars and Symposium, October 3-10, San Antonio, Texas, USA

5 http://www.learn4good.com / jobs / language / english / search / job / 13807 / 12 / 29 /2005 risk mgmt.

6 Indian Standard 4926-2003, Bureau of Indian Standard, New Delhi

7 Johnson, J., and Rood, O. E. (1977) Elements of a fair and equitable profit determination for construction contract negotiations, Draft Report CERL.

8 Mason, G. E. (1973), A quantitative risk management approach to selection of construction contract provisions, Technical Report no 173, Construction Institute, Deptt. of Civil Engrg., Stanford Uni.,Stanford , California

9 PMBOK (2004), A Guide to the project Management body of knowledge, Edition 2004, Project Management Institute

10 Thomas a. Carbone and Donald D. Tippett.(2004), Project Risk Management Using the Project Risk FMEA, Engineering Management journal, Volume 16, No. 4

11 Terry Lyons and Martin Skitmore (2004), Project risk management in the Queensland engineering construction industry: a survey, International journal of Project Management, Vol.22 (2004), pp 51-61

12 Zia,H.(1995),Risk management for overseas construction projects, International journal of Project Management,Vol.13,No. 4, pp 231-237. 